\title{
A Study of the Impact of Project Managers' Power and Influence on their Organisation's Project Management Maturity
}

\author{
Virginia Shahida Ngonda $^{1 *}$ and Larry E. J owah² \\ ${ }^{1}$ Department of Industrial and Systems Engineering, Cape Peninsula University of Technology, P.O. B ox 1906, \\ Bellville, South A frica \\ ${ }^{2}$ Department of M anagement and Project M anagement, Cape Peninsula University of Technology, P.O. B ox 1906, \\ B ellville, South A frica
}

\begin{abstract}
Project managers are determinants of their organisations' project management maturity as their competence is one of the factors that affect their organisations' capability of an organisation to successfully execute projects. This capability of an organisation is reflected in its project management maturity. The study reported in this conference paper sought to investigate whether there is a correlation between South African project managers' power and influence on their organisation's project management maturity. This was done to determine if project managers have sufficient power to influence their organisation's project management maturity. The paper reports on a nation-wide survey that collected data from self-identified project managers. It received three hundred and six valid responses which were edited, coded, and analysed descriptively and inferentially. The study found weak positive correlations between project managers' power, project managers' technical expertise and their organisations' project management maturity. Thus, as project managers' power and technical expertise increase, it is likely that their organisation's project management maturity also increases. However, causation could not be established as it was not possible to establish the temporal order amongst the variables. The established correlations were too weak to be used for prediction.
\end{abstract}

Keywords: organisation, power, project management maturity, project management maturity model, project manager

\section{Introduction}

Formal ised project management posts are a recent addition to South A frican organisations. In a 2013 study, Labuschagne et al. [1] claim that only 35\% were senior enough to influence change in their organisations. This presents a challenge as by and large a project is a specialised undertaking which requires unique competencies from the project leader

\footnotetext{
* Corresponding author: ngondas@ cput.ac.za
} 
to meet the requirements of the iron triangle - the triple constraints of time, budget and scope [2]. In addition, a project requires an enabling environment. The larger the project, the more likely it is to be complex and interdisciplinary. Thus, involving the formation of interdisciplinary teams to participate in the creation of this unique structure. Projects are characterised by high failure rates, high risks, team conflicts, and many other unique problems.

The project execution process involves the ability to apply the requisite knowledge, appropriate skills, relevant tools and ideal techniques in the process of creating the project product [3]. The success of the project execution process is generally mandated to the project leader. Hence, the existence of is a common belief by senior executives that "picking the right project manager" is the answer for the success of the project execution [4]. However, this is one side of the equation as other functionaries (the project team and the project organisation) has a bearing on the effectiveness of project execution [5].

The parent organisation structures and practices may provide a framew ork that can aid or hinder project success [6]. The maturity of an organisation can be evaluated based on its ability to provide adequate support, manage the resources, and nurture the project management talent [7]. The ability of an organisation is to practice project management principles that permeate through the entire organisation demonstrates project management maturity [8]. Such an organisation provides structural support for the implementation of projects within itself at all levels.

The concept of project management maturity is used to provide an indication of an organization's capability to manage projects [9]. The more project management mature organisation is more likely to achieve higher overall project success, has less scope creep and less cost and schedule variation. Cooke-Davies and A rzymanow [7] concur with the above that higher maturity reduces variations in an organisation's project execution effectiveness. To measure project management maturity, various project management maturity models have been developed. The project management community uses many more project management maturity models. Grant and Pennypacker [10] report that there were more than 30 maturity models that were used with none receiving worldwide acceptance. A rchibald and A rchibald [11] report that by the end of the decade, 2006-2016, the number of project management maturity models had grown to hundreds, covering all types of industries.

The link between the project manager and the project organisation is often ignored in the literature on project management maturity. The study reported in this paper seeks to establish a relationship between project managers' attributes and their organisations' project management maturity. To achieve this, the study evaluated the existence of the statistical association, correlation or causation between the project managers' power, project managers' technical expertise, and project managers' project management experience and their organisations' project management maturity. If relationships amongst the parameters exits, then project managers cannot be ignored in initiatives which organisations embark on to improve their project management maturity.

\section{Project management maturity models}

The majority of (most) project management models measure project management maturity of a five-level ordinal scale following the structure of the first project management maturity model, Software Engineering Institute's Capability Maturity Model (SEI-CM M ). SEI-CM M was developed for assessing the capability of an organisation's software development process [12]. SEI-CM M describes the key elements of an effective software development process. SEI-CMM can be used to evaluate an organisation's software development processes against standard criteria and allocate an organisation's maturity to one of its five levels of maturity. 
The SEI used a US government grant to adapt the CM M for assessment of organisations' effectiveness in managing non-software projects [13]. The maturity levels for a generalised capability maturity model that was termed Capability Maturity Model Integration (SEICM M I) are described in Table 1.

Table 1. M aturity levels in the SEI-CM M I

\begin{tabular}{|c|c|}
\hline $\begin{array}{l}\text { Maturity } \\
\text { Levels }\end{array}$ & Description \\
\hline $\begin{array}{l}\text { Level } 5 \\
\text { (Optimising) }\end{array}$ & $\begin{array}{l}\text { Continuous improvement using both quantitative and qualitative data generated } \\
\text { from previous and current projects is practised. Innovation in both processes and } \\
\text { project management tools is routine. }\end{array}$ \\
\hline $\begin{array}{l}\text { Level } 4 \\
\text { (M anaged) }\end{array}$ & $\begin{array}{l}\text { M etrics are collected for both products and processes. All projects are carefully } \\
\text { monitored and controlled. }\end{array}$ \\
\hline $\begin{array}{l}\text { Level } 3 \\
\text { (Defined) }\end{array}$ & $\begin{array}{l}\text { Standardisation and documenting of project process becomes the norm. } \\
\text { The organisation develops its own way of managing projects. Each } \\
\text { section/department manages projects in the same way. }\end{array}$ \\
\hline $\begin{array}{l}\text { Level } 2 \\
\text { (Repeatable) }\end{array}$ & $\begin{array}{l}\text { Project management processes are in place and track the triple constraints of each } \\
\text { project: time, cost, and requirements. Lessons learned are used in the execution } \\
\text { of similar projects. Project success can be repeated for similar projects. }\end{array}$ \\
\hline $\begin{array}{l}\text { Level } 1 \\
\text { (Initial) }\end{array}$ & $\begin{array}{l}\text { Project management process is ad hoc or even chaotic. The organisation does not } \\
\text { provide support for the project manager. Success in projects depends on the } \\
\text { competency and the effort of individual project managers. While organisations } \\
\text { in this level can succeed in a project, success is not often repeatable. }\end{array}$ \\
\hline
\end{tabular}

Over the years, other project management models have been developed. Project management maturity models are divided into three broad categories: technical delivery process models, project management process models and organisational maturity models. SEI-CMM and other technical delivery process models focus on documenting project management processes and increasing the level of application on standardised project management processes within an organisation. Project management process models are an evolution of the technical delivery process models where they can apply the same concept of increased capability within the context of an organisation which practises project management based on a standard such as PMBOK or PRINCE2. PM S-PM M M is an example of such a model that integrates the capability structure of SEI-CMM. Organisational maturity models go beyond project management and review the entire organisation. They can be applied to organisations that are not project-orientated. Table 2 provides examples of the models and highlight their evolution.

Table 2. K ey developments in the evolution of project management maturity models

\begin{tabular}{lll}
\hline Year & Model & Developer and application \\
\hline 1986 & Capability M aturity M odel (CM M) & $\begin{array}{l}\text { Developed by Carnegie M ellon University } \\
\text { Software Engineering Institute to access } \\
\text { software development capability }\end{array}$ \\
\hline 2000 & $\begin{array}{l}\text { Kerzner Project M anagement M aturity } \\
\text { M odel (K erzner-PM M M ) }\end{array}$ & $\begin{array}{l}\text { Devel oped by Harold Kerzner as a generic } \\
\text { model that was meant to extend CM M } \\
\text { into general project management }\end{array}$ \\
\hline 2002 & $\begin{array}{l}\text { Berkeley Project M anagement Process } \\
\text { M aturity M odel, (PM ) }\end{array}$ & $\begin{array}{l}\text { Developed by Y oung K wak and W illiam Ibbs } \\
\text { as a generic model that the encompassed key } \\
\text { project management knowledge areas and key } \\
\text { processes that occur within the knowledge areas }\end{array}$ \\
\hline 2002 & $\begin{array}{l}\text { Project M anagement M aturity M odel } \\
\text { (PM S-PM M M ) }\end{array}$ & $\begin{array}{l}\text { Developed by PM Solutions as a generic model } \\
\text { that is aligned with the PM BOK knowledge } \\
\text { areas }\end{array}$ \\
\hline
\end{tabular}




\begin{tabular}{lll}
\hline 2003 & $\begin{array}{l}\text { Organizational Project M anagement } \\
\text { M aturity M odel (OPM 3) }\end{array}$ & $\begin{array}{l}\text { Released by the PM I-USA as a generic } \\
\text { organisation-wide model for project, } \\
\text { programme, and portfolio management maturity } \\
\text { assessment }\end{array}$ \\
\hline 2009 & PRINCE2 M aturity M odel (P2M M ) & $\begin{array}{l}\text { Developed by United Kingdom's Office } \\
\text { of Government Commerce to support maturity } \\
\text { assessments in organisations that are using } \\
\text { PRINCE2 }\end{array}$ \\
\hline
\end{tabular}

Project management maturity models are not silver bullets that solve project management capability challenges. Cooke-Davies [14] warns that project maturity models do not confer a competitive advantage to an organisation, but they are rather a valuable tool that can assist an organisation in its quest for project management excellence. Perhaps the value of the models can be appreciated when one considers anecdotal evidence of project success rates of organisations that have low maturity levels. In a Brazilian study, Prado, Oliveira and Romano [15] found that there is a direct positive relationship between project management maturity and project success. They found that as project maturity increased from 1 to 5 , project success also increased from $38.7 \%$ to $81 \%$. Conversely, as maturity decreased from 5 to 1 , the project failure rate increased from $5 \%$ to $18.6 \%$. Other researchers reported similar findings as well.

\section{Relationship between project management maturity and the project manager}

An organisation's project management maturity depends on the competency of its staff, particularly that of the project manager [4]. Competency is "the ability to mobilise, integrate and transfer knowledge, skills and resources to reach or surpass performance in work assignments adding economic and social value to the organisation" [16]. Although the competency of a project manager cannot be directly measured it can be inferred from personal attributes such as qualifications, experience, attitudes, and behaviours [4]. Project management associations have recognised the impact of project managers on project management success such that they have introduced frameworks for assessing and certifying PM competencies [16].

Chipulu, Neoh, Ojiako and Williams [17] investigated and mapped key project manager competencies from a study of project manager recruitment adverts from all over the world. They found that employers sought project management knowledge and expertise as evidence of project management qualifications, certifications, and years of project management experience. They also found that employers sought senior managerial experience that can provide strategic leadership as well as manage change. High emotional intelligence and understanding of professional ethics were also sought. Lastly, highly sought project managers are expected to be experts in risk management.

A project manager is defined as an individual who is responsible for managing a project [18]. It is not a title that makes one a project manager. Gray and Larson [18], correctly note that most people who manage projects do not carry a project manager title, suggesting that the function is unique given the unique nature of the projects themselves. Crawford [4] concurs and posits that their function goes beyond mere coordination of activities to implement a plan since they are liable for the success or failure of the project execution process.

Effective project managers are essentially leaders in that they too often do not have the formal authority [19]. However, Mersino [20] notes that like other managers, project managers are expected to be able to get work done. M azibuko, Tait and Jowah [21] concur 
and assert that project leaders have a serious problem because they have an authority gap (no formal authority) and thus find themselves having to develop other competencies to enable them to overcome the authority gap and deliver on expectations. The issues of power and influence are very crucial as, according to M ersino [20], project managers achieve their objectives through the work done by other people whom the project manager has no functional authority over.

\section{Research design}

The study reported in this conference paper adopted a correlational survey methodology. The study used a questionnaire that based on concepts of Kerzner's Project Management Maturity Model and project managers' attributes that were developed by Cooke-Davies and A rzymanow [7] to collect data from self-identified South A frican project managers by their membership of a project management association. An invitation to participate in the study, with a link to the online questionnaire, was published in the selected association's newsletter that was sent to all their members. The invitation was sent out in J anuary 2017 and by February 2017, three hundred and six completed responses were received.

The data was cleaned and edited for any errors and omissions that were identified, the questions were coded, and the information was captured onto a spreadsheet. After the preparation, analysis of the response data was conducted using a commercial statistical analysis package. The data was analysed $\mathrm{ii}_{\mathrm{i}}$ in two ways. First, data were analysed to provide means, percentage, and standard deviations of the variables. This data was then converted to illustrations in the form of tables, pie charts, histograms, and bar charts. Secondly, hypotheses testing was conducted using the Pearson Chi-Squire test of independence [22]. This analysis provided information on the basis on which generalisations may be made to the research findings.

\section{Findings and discussion}

The study found that in South A frica, the project management profession is relatively STEM orientated and comprise relatively older, more qualified, and more experienced practitioners. The respondents had media age 37.58 years, most worked in IT $(59.1 \%)$ followed by construction and engineering (23.5\%). B oth are in STEM . In addition, most respondents had a postgraduate degree $(73.5 \%)$, followed by those with a degree $(18.6 \%)$ and lastly those with a diploma (7.8\%). Lastly, it seems that project management in South A frica is a relatively male-dominated profession. This might reflect on the fact that STEM in South A frica is male-dominated.

The study showed that South A frican project management industry has slightly matured since the 2013 PM SA commissioned a study by Labuschagne et al. [1]. When compared with global trends, the perceived maturity of South A frican organisations is still very low, although, there are pockets of high maturity. $8.2 \%$ of the respondents' companies had achieved a perceived maturity of five. $42.2 \%$ of the organisations had a project management maturity of three. M ost of the organisations were practising aspects of project management and had structures that would support a higher maturity than what they were currently at.

As shown in Table 3, a test of association using Spearman's rho and partial correlation test indicated that project managers' power and their organisation $₫$ project management maturity are not independent of each other. The association is significant. A correlation test revealed a weak positive relationship between the two. Thus, as project managers' power increases, it is likely that their organisation's project management maturity also increases. The study did attribute the organisation's improvement to the increase in project managers' 
power as the study would not establish the temporal order between the two. Similar tests for project management maturity and project managers' technical expertise also revealed that as project managers' technical expertise increases, it is likely that their organisation's project management maturity also increases. Like before, temporal order could not be established.

Table 3. Spearman's correlation for project managers' power, influence, project managers' project management experience, project managers' technical expertise and project management maturity

\begin{tabular}{|c|c|c|c|c|c|}
\hline & & $\begin{array}{c}\text { Project } \\
\text { managers' } \\
\text { influence }\end{array}$ & $\begin{array}{c}\text { Project } \\
\text { managers' } \\
\text { power }\end{array}$ & $\begin{array}{c}\text { Project } \\
\text { managers' } \\
\text { technical } \\
\text { expertise }\end{array}$ & $\begin{array}{c}\text { Project } \\
\text { managers' } \\
\text { project } \\
\text { management } \\
\text { experience }\end{array}$ \\
\hline \multirow{2}{*}{$\begin{array}{l}\text { Project } \\
\text { managers' } \\
\text { influence }\end{array}$} & $\begin{array}{l}\text { Correlation } \\
\text { Coefficient }\end{array}$ & & & & \\
\hline & $\begin{array}{l}\text { Sig. (2- } \\
\text { tailed) }\end{array}$ & & & & \\
\hline \multirow{2}{*}{$\begin{array}{l}\text { Project } \\
\text { managers' } \\
\text { power }\end{array}$} & $\begin{array}{l}\text { Correlation } \\
\text { Coefficient }\end{array}$ & $.730^{* *}$ & & & \\
\hline & $\begin{array}{l}\text { Sig. (2- } \\
\text { tailed) }\end{array}$ & 0.000 & & & \\
\hline \multirow{2}{*}{$\begin{array}{l}\text { Project } \\
\text { managers' } \\
\text { technical } \\
\text { expertise }\end{array}$} & $\begin{array}{l}\text { Correlation } \\
\text { Coefficient }\end{array}$ & .055 & $.126^{*}$ & & \\
\hline & $\begin{array}{l}\text { Sig. (2- } \\
\text { tailed) }\end{array}$ & 0.335 & 0.028 & & \\
\hline \multirow{2}{*}{$\begin{array}{l}\text { Project } \\
\text { managers' } \\
\text { project } \\
\text { management } \\
\text { experience }\end{array}$} & $\begin{array}{l}\text { Correlation } \\
\text { Coefficient }\end{array}$ & .108 & .083 & $.131^{*}$ & \\
\hline & $\begin{array}{l}\text { Sig. (2- } \\
\text { tailed) }\end{array}$ & 0.059 & 0.150 & 0.022 & \\
\hline \multirow{2}{*}{$\begin{array}{l}\text { Project } \\
\text { management } \\
\text { maturity of } \\
\text { organisation }\end{array}$} & $\begin{array}{l}\text { Correlation } \\
\text { Coefficient }\end{array}$ & $.191^{* *}$ & $.292^{* *}$ & $-.137^{*}$ & $.113^{*}$ \\
\hline & $\begin{array}{l}\text { Sig. (2- } \\
\text { tailed) }\end{array}$ & 0.001 & 0.000 & 0.016 & 0.049 \\
\hline
\end{tabular}

The study found that although project management maturity and project managers' project management experience as indicated these are not independent of each other, their association was spurious as it was mediated by project managers' power (see Table 4). Similar findings were made about project managers' influence and their organisations' project management maturity. In this case, project managers' power was also the mediating variable. Partial correlation of project managers' technical expertise yielded a significance value of 0.000 , which is below the 0.01 value that indicates significance. Thus, only project managers' power and technical expertise are correlated with project management maturity. Inspection of Table 3 shows that correlation between project managers' technical expertise and project management is only significant at the 0.05 level. 
Table 4. Partial correlation of project managers' influence, technical expertise and project management experience, and project management maturity with project managers' power as the mediating variable

\begin{tabular}{|c|c|c|c|c|}
\hline & & $\begin{array}{c}\text { Project } \\
\text { managers' } \\
\text { influence }\end{array}$ & $\begin{array}{c}\text { Project } \\
\text { managers' } \\
\text { technical } \\
\text { expertise }\end{array}$ & $\begin{array}{l}\text { Project managers' } \\
\text { project management } \\
\text { experience }\end{array}$ \\
\hline $\begin{array}{l}\text { Project } \\
\text { managers' } \\
\text { influence }\end{array}$ & $\begin{array}{l}\text { Correlation } \\
\text { Significance (2- } \\
\text { tailed) }\end{array}$ & & & \\
\hline $\begin{array}{l}\text { Project } \\
\text { managers' } \\
\text { technical } \\
\text { expertise }\end{array}$ & $\begin{array}{l}\text { Correlation } \\
\text { Significance (2- } \\
\text { tailed) }\end{array}$ & $\begin{array}{l}-.054 \\
0.349\end{array}$ & & \\
\hline $\begin{array}{l}\text { Project } \\
\text { managers' } \\
\text { project } \\
\text { management } \\
\text { experience }\end{array}$ & $\begin{array}{l}\text { Correlation } \\
\text { Significance (2- } \\
\text { tailed) }\end{array}$ & $\begin{array}{l}.087 \\
.128\end{array}$ & $\begin{array}{l}.161 \\
.005\end{array}$ & \\
\hline $\begin{array}{l}\text { Project } \\
\text { management } \\
\text { maturity of } \\
\text { organisation }\end{array}$ & $\begin{array}{l}\text { Correlation } \\
\text { Significance (2- } \\
\text { tailed) }\end{array}$ & $\begin{array}{l}.027 \\
0.636\end{array}$ & $\begin{array}{l}.282^{* *} \\
0.000\end{array}$ & $\begin{array}{l}.044 \\
0.449\end{array}$ \\
\hline
\end{tabular}

The study indicates that project managers, particularly the power that they have in their organisations, cannot be ignored in initiatives that organisations embark on to improve their project management maturity. It shows that an organisation's project managers' power and technical expertise have an influence on its project management maturity. Thus, to guarantee project management maturity, organisations should assist their project managers to develop their technical expertise. For example, organisations could assist their project managers to develop expert power, which is based on the individual's relevant experience and knowledge for the team to complete the task [23]. They could facilitate their project managers to achieve certification such as PMI-USA's PMP certification, a certification from the South A frican Council for Project and Construction M anagement Professions, or any other reputable body whose members are perceived to be project management experts. In addition, project managers can be granted connection power which is not related to someone's position in the organisation or team but rather tied to the connection to power players that an individual might have [24]. Having a visible executive sponsor might provide the required connection power. Facilitating access to power would assist in narrowing the authority gap of project managers by giving their sufficient authority. Their organisations would benefit from this as project managers would be able to implement the changes that are required for project management maturity improvement.

\section{Conclusion}

The study found that there are non-spurious relationships between project managers' power and their organisations' project management maturity and between project managers' technical expertise and their organisations' project management maturity. The study did not find statistical evidence supporting the existence of relationships between project managers' influence and their organisations' project management maturity, between project managers' 
project management experience and their organisations' project management maturity, and between project managers' technical expertise and their organisations' project management maturity. The findings of this study indicate that organisation s would benefit if they facilitated the project managers' efforts to narrow their authority gap through the acquisition of expert and connection power.

\section{References}

1. L. Labuschagne, C. Marnewick, M. Eloff, H. Steyn, P. Tobin, Project M anagement $M$ aturity vs Project Outcomes in A frica (Project M anagement South A frica, Pretoria, 2013)

2. H. K erzner, Project M anagement B est Practices: A chieving Global Excellence, 3rd ed., New Jersey, USA: Wiley (2014)

3. Project M anagement Institute, A Guide to the Project Management Body of Knowledge (PMBOK Guide), 4th ed., Pennsylvania, USA : Project M anagement Institute (2008)

4. L. Crawford, Senior M anagement Perceptions of Project M anagement Competence, International Journal of Project Management 23(1): 7-16 (2005)

5. J.M. Nicholas, H. Steyn, Project Management for Engineering, Business and Technology, 4th ed., London, UK: Routledge (2012)

6. Project M anagement Institute, A Guide to the Project Management Body of Knowledge (PMBOK Guide), 5th ed., Pennsylvania, USA : Project M anagement Institute (2013)

7. T.J. Cooke-Davies, A. A rzymanow, The $M$ aturity of Project $M$ anagement in Different Industries: An Investigation into $V$ ariations between Project $M$ anagement $M$ odels, International Journal of Project Management 21(6): 471-478 (2003)

8. J. Farrokh, A.K. M ansur, Project M anagement M aturity Models and Organizational Project $M$ anagement Maturity Model (OPM 3): A Critical Morphological Evaluation, Project Management 2(7): 23-33 (2013)

9. C.W. Ibbs, J.M. Reginato, Y.H. K wak, Developing Project M anagement Capability: Benchmarking, Maturity, Modeling, Gap Analyses, and ROI Studies. In J.K. Pinto P.W.G. M orris (eds.), The Wiley Guide to Managing Projects, N ew Jersey, USA : Wiley, 1214-1233 (2004)

10. K.P. Grant, J.S. Pennypacker, Project M anagement M aturity: A n A ssessment of Project $M$ anagement Capabilities among and between Selected Industries, IEEE Transactions on Engineering Management 53(1): http://ieeexplore.ieee.org//pdocs/epic03/w rapper.htm?arnumber=1580894

11. R.D. Archibald, S.C. A rchibald, Leading and Managing Innovation: What Every Executive Team Must Know about Project, Program, and Portfolio Management, 2nd ed., Boca Raton, USA : CRC (2016)

12. G.A. Kumta, M.D. Shah, Capability M aturity M odel, Delhi Business Review 3(1) (2002)

13. M. Paulk, A Comparison of ISO 9001 and the Capability Maturity Model for Software, Pittsburgh, USA : Carnegie M ellon University (1994)

14. T. Cooke-Davies, Project $M$ anagement $M$ aturity M odels. In J.K. Pinto, P.W.G. M orris (eds.), The Wiley Guide to Managing Projects, New Jersey: USA : Wiley, 1234-1255 (2007)

15. D. Prado, W.A. de Oliveira, L.M. Romano, Project Management Maturity Research Report 2014: "General Report" Part A: Indicators (2015), http://www.maturityresearch.com/novosite/en/index.html

16. S.M. Takey, M.M. de Carvalho, Competency Mapping in Project Management: An A ction Research Study in an Engineering Company, International Journal of Project Management 33(4): 784-96 (2015) 
17. M. Chipulu, J.G. Neoh, U. Ojiako, T. Williams, A M ultidimensional A nalysis of Project $\mathrm{M}$ anager Competences, IEEE Transactions on Engineering Management 60(3): 506-17 (2013)

18. C.F. Gray, E.W. Larson, Project Management: The Managerial Process, 5th ed., New Y ork, USA: M cGraw-Hill/Irwin (2011)

19. T. Roeder, Managing Project Stakeholders: Building a Foundation to Achieve Project Goals, New Jersey, USA : Wiley (2013)

20. A. M ersino, Emotional Intelligence for Project Managers, 2nd ed., N ew Y ork, USA: A merican M anagement A ssociation (2013)

21. N.E. M azibuko, M. Tait, L.E. J owah, Critical Core Competencies Required for Effective Project Leadership in the Presence of the Authority Gap, Journal of Contemporary Management 12: 313-35 (2015)

22. M. Saunders, P. Lewis, A. Thornhill, Research Methods for Business Students, 5th ed., Edinburgh, UK: Pearson (2009)

23. J. Schermerhorn, J.G. Hunt, R.N. Osborn, Organizational Behaviour, 7th ed., N ew Y ork, USA : Wiley (2002)

24. Elearn Limited, Leadership and M anagement in Organisations, Oxford, USA: Elsevier (2007) 